\title{
НЕЙРОПЕПТИДНЫЕ СИГНАЛЬНЫЕ СИСТЕМЫ МОДУЛИРУЮТ ПОСТ-СТРЕССОРНЫЙ ОТВЕТ У КОСТИСТОЙ РЫБЫ DANIORERIO
}

\section{П.П. Хохлов, А.А. Блаженко, А.С. Девяшин, Е.Р. Бычков, А.А. Лебедев, П.Д. Шабанов}

Отдел нейрофармакологии им. С.В.Аничкова,

ФГБНУ «Институт экспериментальной медицины», 197376, Санкт-Петербург, Россия.

DOI: 10.19163/MedChemRussia2021-2021-98

E-mail: platonkh@list.ru

Конкретные молекулярные и клеточные механизмы реакций на стресс остаются невыясненными, особенно для рыб и других групп низших позвоночных. Цель настоящей работы состояла в том, чтобы оценить роль пептидов «цепи пищевого поведения» в пост-стрессорных реакциях у рыбы Daniorerio (Cyptinidae, Cypriniformes, Teleostes), которая хорошо известна в качестве удачного модельного организма.

В работе использовали особей размером 18-25 мм и весом $\approx 500$ мг (самцы и самки). В качестве стрессорного воздействия применяли экспозицию с хищной рыбой. Далее животных анестезировали и вылеляди у них образцы отделов головного мозга и мышцы хвоста. Гомогенаты выделенных тканей исследовании с помощью твердофазного иммуноферментного анализа. Определяли концентрации грелина, орексина и КРГ. Общий уровень стресса определяли путем измерения концентрации кортизола в мышце хвоста.

Измерение кортизола в мышце хвоста D.rerio отражает общий уровень пост-стрессорного состояния животного. Экспозиция с хищником приводила к значимому возрастанию уровня кортизола. Уровень кортизола значимо снижался после введения антагониста грелина в сравнении в животными контрольной группы. Мы приняли уровень кортизола в хвостовой мышце в качестве количественной оценки уровня стрессорного воздействия. В работе использовали образцы переднего мозга, средний мозга и заднего мозга - продолговатый мозг и мозжечок. В результате экспозиции хищнику происходило перераспределение концентраций грелина орексина и КРГ между отделами мозга. После экспозиции уровень грелина был значимо снижен в образцах заднего мозга и, наоборот, повышен в образцах переднего и среднего мозга.

Грелин, орексин и некоторые другие нейропептиды сигнальных систем пищевого поведения у D.rerio одновременно принимают участие в цепи реакций в качестве ответа на стрессорноепсихо-эмоциональноевоздействие. Грелиновая, орексиновая и КРГ сигнальные системы можно рассматривать как возможные мишени для фармакологической коррекции пост-стрессорного состояния. 